\title{
PENANGANAN COVID-19 DALAM PERSPEKTIF PENTAHELIX (STUDI KASUS DI KOTA PEKALONGAN)
}

\author{
Rr. Vita Nur Latif*, Isrofah, Ardiana Priharwanti \\ Universitas Pekalongan \\ Jalan Sriwijaya No 3 Pekalongan \\ Korespondensi : diana.arif25@gmail.com
}

\begin{abstract}
Abstrak
The development of the pandemic in Pekalongan from the beginning of March 2020 to today is a total of 69 confirmed positive cases, with details: 8 people were treated, 12 people were isolated independently, 35 people recovered, 7 people died. To be able to reduce the prevalence rate of cases which continues to show a significant increase, a synergistic control scenario is needed with the optimization of the role of the pentahelix (government, society, academia, private sector, health service providers). Methods. This study used an exploratory research design with a qualitative approach. The research subjects which contained elements of the pentahelix (government, society, academics, private sector, health service providers). Result. Based on the research findings on the role and optimization of pentahelix, all elements of pentahelix (government, academics, society, media and the private sector) have all taken roles even though there are several implementation obstacles in the field, especially in the profile and level of community compliance, particularly in public facilities such as traditional markets, pilgrimages. sapuro, religious activities and others.
\end{abstract}

Keywords: Pentahelix, Covid-19

\section{PENDAHULUAN}

Sampai dengan tanggal 3 September 2020 , jumlah angka kematian akibat Covid-19 di Kota Pekalongan sebanyak 7 orang. Adapun kasus konfirmasi positif berada pada angka 69 orang. Menurut estimasi epidemiologis mestinya dilaksanakan pemeriksaan skrining/rapid test maupun swab test minimal 5\% dari total jumlah penduduk untuk dapat mengetahui angka IR (insiden rate/angka kejadian) yang mendekati representasi, sehingga fenomena kasus gunung es diharapkan tidak akan terjadi, mengingat jika memperhatikan pola pergeseran tingkat awarness/kesadaran dan tingkat kepatuhan masyarakat di Kota Pekalongan yang semakin menurun semenjak pemberlakuan pola kebiasaan baru, memungkinkan terjadi fenomena tersebut, di mana jumlah angka kasus yang sebenarnya kemungkinan melebih angka terkonfirmasi positif.

Jika memperhatikan pola penyebaran kasus dan kejadian pandemi Covid-19 di Kota Pekalongan, maka dapat diilustrasikan bahwa pola perkembangan kasus dan perubahan pola perilaku masyarakat tampak dalam ilustrasi grafik di bawah ini.

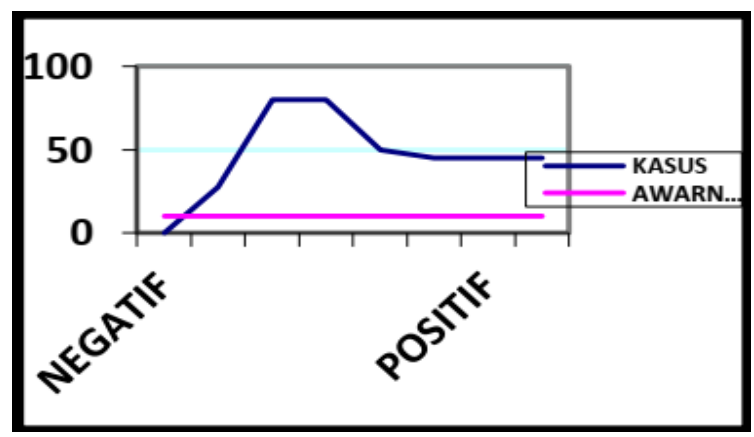

Gambar 1 Ilustrasi perbandingan terbalik pola kecenderungan penurunan awareness masyarakat dengan adanya peningkatan kasus Covid-19

Untuk dapat menekan angka prevalensi kasus yang terus menunjukkan peningkatan yang signifikan, maka diperlukan skenario pengendalian yang sinergis dengan optimalisasi peran pentahelix (pemerintah, masyarakat, akademisi, swasta, fasilitas pemberi pelayanan kesehatan). Pemerintah mengambil peran dalam model kebijakan yang diambil guna menekan laju peningkatan prevalensi (pemberlakuan social distancing, peliburan akademik 14 hari, 
dan lain sebagainya), masyarakat (mengambil peranan aktif dalam penerapan PHBS yang mengedepankan aspek pencegahan transmisi Covid-19, seperti: kepatuhan penerapan social distancing, stay at home, germas, self isolation, etika batuk, dan lain sebagainya), akademisi (melalui pengembangan riset dan pengabdian masyarakat berupaya menekan laju peningkatan prevalensi kasus Covid-19).

\section{TINJAUAN PUSTAKA}

\subsection{Pengertian Penanggulangan Bencana}

Penanggulangan bencana, mitigasi bencana didefinisikan sebagai: "Upaya untuk mengurangi risiko bencana, baik melalui pembangunan fisik maupun penyadaran dan peningkatan kemampuan menghadapi ancaman bencana" (Pasal 1 ayat 6 PP No 21 Tahun 2008)

\subsection{Pandemi Covid-19}

Adalah peristiwa menyebarnya penyakit koronavirus 2019 (coronavirus disease 2019, disingkat Covid-19) di seluruh dunia. Penyakit ini disebabkan oleh koronavirus jenis baru yang diberi nama SARS-CoV-2. Wabah Covid-19 pertama kali dideteksi di Kota Wuhan, Provinsi Hubei, Tiongkok pada bulan Desember 2019, dan ditetapkan sebagai pandemi oleh Organisasi Kesehatan Dunia (WHO) pada 11 Maret 2020. Hingga 28 Maret, lebih dari 620.000 kasus Covid-19 telah dilaporkan di lebih dari 190 negara dan teritori, mengakibatkan lebih dari 28.800 kematian dan 137.000 kesembuhan (Mona, 2020)

\subsection{Situasi Global, nasional serta regional}

Angka mortalitas dan morbiditas secara keseluruhan karena infeksi virus belum ditetapkan dengan baik, sementara tingkat fatalitas kasus berubah dari waktu ke waktu dalam pandemi koronavirus ini. Perbandingan infeksi yang berkembang menjadi penyakit yang dapat didiagnosis tetap tidak jelas. Namun, penelitian pendahuluan telah menghasilkan tingkat kematian kasus antara $2 \%$ hingga 3\% dan WHO mengusulkan bahwa tingkat kematian kasus adalah sekitar 3\% pada Januari 2020. Sebuah studi pra-cetak Imperial College London menerangkan pada 55 kasus fatal mencatat bahwa perkiraan awal kematian mungkin terlalu tinggi karena infeksi asimptomatik tidak terjawab. Mereka memperkirakan rasio fatalitas infeksi rata-rata (mortalitas di antara yang terinfeksi) berkisar dari $0,8 \%$ ketika termasuk pembawa asimptomatik hingga $18 \%$ ketika hanya memasukkan kasus simptomatik dari provinsi Hubei. Data penderita positif Corona tertanggal 31 Maret 2020 di dunia negara terdampak 199 Negara dengan 785.777 kasus dan kemataian 37.815.

Pandemi Covid-19 di Indonesia diawali dengan temuan penderita pada 2 Maret 2020. Sampai tanggal 29 Maret 2020, telah terkonfirmasi 1.285 kasus positif Covid-19. Kasus dinyatakan tersebar di 31 provinsi dari total 34 provinsi di Indonesia. Tiga provinsi tanpa laporan kasus terkonfirmasi yaitu Bengkulu, Gorontalo, dan Nusa Tenggara Timur. (https://covid19.go.id/).

Pekalongan sebagai Kota Batik merupakan daerah yang rawan terkena pandemik Covid-19. Sebagai langkah tanggap dengan penularan virus corona, serta menindaklanjuti Keputusan Presiden No. 7 Tahun 2020 mengenai Gugus Tugas Percepatan Penanganan Covid-19, Pemerintah Kota Pekalongan membentuk Gugus Tugas Percepatan Penanganan Covid-19. Upaya ini dilakukan karena virus corona kini berstatus pandemik global sehingga sudah menjadi bencana non alam.

Jumlah pasien terkonfirmasi positif 1 orang, meninggal 1 orang, ODP (Orang dalam Pemantauan) berjumlah 32 orang, dan PDP 4 orang. (https://corona.pekalongankota.go.id).

2.4. Optimalisasi peran pentahelix dalam pandemik Covid-19

Peran pentahelix yang dimaksud adalah (pemerintah, masyarakat, akademisi, swasta, fasilitas pemberi pelayanan kesehatan). Pemerintah mengambil peran dalam model kebijakan yang diambil guna menekan laju peningkatan prevalensi (pemberlakuan social distancing, peliburan akademik 14 hari, dan lain sebagainya), masyarakat (mengambil peranan aktif dalam penerapan PHBS yang mengedepankan aspek pencegahan transmisi Covid-19, seperti: kepatuhan penerapan social distancing, stay at home, germas, self isolation, etika batuk, dan lain sebagainya), akademisi (melalui pengembangan riset dan pengabdian 
masyarakat berupaya menekan laju peningkatan prevalensi kasus Covid-19).

\section{METODE}

Desain penelitian ini menggunakan desain penelitian exploratory research dengan pendekatan kualitatif yang didukung dengan data statistik dengan triangulasi sumber melalui indepth interview pada informan utama, dan informan pendamping untuk mencari apersepsi berbagai sumber. Instrumen penelitian menggunakan guidence interviewing. Fokus penelitian ini mengkaji strategi mitigasi pencegahan dan penanggulangan pandemi Covid-19 melalui analisis peran peran pentahelix. Subyek penelitian meliputi informan utama dan informan triangulasi, yang memuat unsur pentahelix (pemerintah, masyarakat, akademisi, swasta, fasilitas pemberi pelayanan kesehatan). Adapun jumlah informan utama dan triangulasi adalah 21 orang yang terdiri dari camat, lurah, Badan Penanggulangan Bencana Daerah (BPBD) Kota Pekalongan, Direktur RS rujukan Covid-19, pengelola mall dan pasar modern.

\section{HASIL DAN PEMBAHASAN}

Persepsi perkembangan Covid-19 di Kota Pekalongan baik di wilayah Kecamatan Barat, Timur, Utara dan Selatan. Hasil penarikan wawancara mendalam dengan keempat camat di Kota Pekalongan menyatakan bahwa selama ini kasus terkonfirmasi berasal dari pendatang, Selama ini tidak ada konfirmasi dari transmisi lokal antar warga Pekalongan.

Hal ini dikuatkan dalam pernyataan camat salah satunya camat Pekalongan Utara.

....Kemarin itu yang positif nahkoda pulang dari layar. jadi dapat dari luar kemudian yang kemarin viral di Krapyak dari pengajian Gowa.

Untuk jumlah tertinggi kasus terkonfirmasi Covid-19 di Kota Pekalongan, berdasarkan wawancara mendalam dengan keempat camat di Kota Pekalongan ada di wilayah Kecamatan Pekalongan Barat. Akan tetapi menurut para camat dan satgas setempat tidak ada kepastian lokus terdampak Covid-19, karena mereka hanya memiliki data jumlah terkonfirmasi positif. Informasi mengenai berapa, siapa yang terkonfirmasi dirasakan oleh sebagian camat kurang cepat dan transparan. Menurut informan informasi tersebut selalu datang ketika salah satu warga dinyatakan meninggal atau sedang dirawat di rumah sakit. Hal ini menurut informan dirasakan cukup menyulitkan dan menjadi kendala bagi mereka untuk melakukan tindakan pencegahan potensi penyebaran di wilayah kerja mereka seperti yang disampaikan dalam penggalan wawancara berikut ini :

untuk data pastinya kami tidak begitu paham dan nuwun sewu bukan menyalahkan tapi selalu terlambat jadi tahunya ya sudah positif saja.

Selama ini kan kami hanya dapat data jumlah, yang kami inginkan adanya transparansi data itu supaya kami bisa melakukan sosialisasi untuk tindakan pencegahan dan masyarakat tidak panik dan tidak ada stigma......

Berdasarkan wawancara mendalam dengan camat tersebut terkait dengan perkembangan kasus Covid-19 di Kota Pekalongan ini memang tidak mendapatkan informasi dengan jelas, sistem koordinasi di dalam satuan gugus kurang berjalan efektif. Jadi untuk jumlah pertambahan dan perkembangannya sejauh mana sebagian besar dari informan menjawab ketidaktahuannya secara pasti dan rinci.

Berdasarkan hasil wawancara mendalam dengan Direktur Rumah Sakit rujukan Covid-19 di Kota Pekalongan, diperoleh informasi bahwa kasus yang terjadi di Kota Pekalongan ini adalah kasus dari luar/pendatang, selama ini belum ada penularan lokal. Terkait dengan sistem rujukan beliau menyampaikan bahwa ada kerja sama yang sudah cukup baik antara rumah sakit, dinas kesehatan, kelurahan dan keluarga jika ada kasus yang terkonfirmasi begitu juga dengan penanganan jenazah kerja sama dengan BPBD Kota Pekalongan telah dilakukan dengan cepat dan sangat baik. Terkait dengan update jumlah kasus terkonfirmasi dan lokus terdampak belum ada data yang pasti dan update menurut keempat camat, walaupun pada saat penanganan kasus terkonfirmasi kerja sama antar elemen seperti dinas kesehatan, rumah 
sakit bahkan BPBD telah dilakukan dengan sangat baik.

Pentahelix yang terdiri dari unsur Pemerintah Kota Pekalongan, Gugus Tugas Percepatan Penanganan Covid-19, OPD terkait baik leading sector maupun lintas sektor, seperti dinas kesehatan, dinas pendidikan, bidang ekonomi, sosial, budaya, maupun unsur BPBD dan RSUD Bendan, aparat (kepolisian, TNI, dan Satpol PP), unsur perguruan tinggi, tokoh masyarakat, tokoh agama, dan masyarakat Kota Pekalongan, telah berelaborasi dalam percepatan penanganan pandemi Covid19 di Kota Pekalongan dengan berbagai upaya yang telah dilakukan, di antaranya berupa penetapan SK Gugus Tugas Percepatan Penanganan Covid-19 di Kota Pekalongan, penerapan jam malam, surat edaran hajatan, penetapan status bencana. Selain itu pemerintah juga melakukan pemandirian masyarakat melalui pemberdayaan masyarakat Kota Pekalongan itu sendiri dimulai dari sosialisasi 4M (memakai masker, mencuci tangan dengan sabun, menjaga jarak, dan menjauhi kerumunan), komunikasi, informasi dan edukasi (KIE) masif sehingga diharapkan mampu menumbuhkan kesadaran/awareness untuk mematuhi protokol kesehatan pencegahan Covid-19. Kegiatan pemberdayaan ini diwujudkan di antaranya dalam pembentukan kelurahan tangguh bencana dan kampus siaga candi.

Kebijakan finansial/dukungan anggaran dilakukan oleh pemerintah dalam bentuk refocusing anggaran. Beberapa alokasi pemerintahan dialokasikan untuk pencegahan dan penanganan Covid-19 di masing-masing wilayah sampai di tingkat kelurahan.

Elaborasi dengan pusat kerumunan dan fasilitas umum seperti pasar, pasar modern, tempat peribadatan dan wisata juga sudah dilakukan dengan baik. Hal ini dibuktikan dengan adanya sosialisasi dari pemerintah kota terkait dengan jam malam dan protokol pencegahan Covid-19. Pembatasan jumlah pengunjung dan penerapan sanksi bagi pengelola pasar modern pun pernah dilakukan oleh pemerintah kota.

Hasil penelitian di empat kantor kecamatan, tiga pasar modern (Hypermart,
Transmart dan Superindo), pada Universitas Pekalongan (sebagai universitas besar di Kota Pekalongan), dan fasilitas umum tempat ibadah dan lainnya telah melaksanakan upaya rekayasa lingkungan yang mengadaptasi kebiasaan baru dengan melengkapi fasilitasi prasarana CTPS (Cuci Tangan Pakai Sabun), pengukuran suhu menggunakan thermogun, pembatasan jumlah kapasitas lift, penanda physical distancing, dan pesan menjauhi kerumunan.

Pengendalian komponen lingkungan juga diwujudkan dalam bentuk rekayasa lingkungan fisik maupun sosial pada saat terdapat pasien terkonfirmasi positif Covid-19 yang meninggal dunia dan dimakamkan di Kota Pekalongan, hasil penelitian menunjukkan kolaborasi antara RSUD Bendan, dinas kesehatan, unsur kecamatan, kelurahan, BPBD, Bhabinkamtibmas telah melaksanakan upaya rekayasa lingkungan fisik berupa pengkondisian lahan pemakaman dan rekayasa sosial dengan melakukan komunikasi efektif sehingga sampai dengan sekarang tidak ada penolakan dari masyarakat sekitar pemakaman maupun anggota keluarga terhadap prosesi pemulasaraan jenazah Covid-19, baik pada pasien yang meninggal yang sudah terkonfirmasi positif maupun pada pasien yang meninggal yang belum terkonfirmasi positif. Upaya KIE kepada masyarakat telah dilakukan oleh pemerintah kota berelaborasi dengan media lokal, rumah sakit, BPBD, maupun pusat perbelanjaan dengan cukup masif. Seperti halnya pemberian KIE masif tentang sosialisasi upaya pencegahan dengan seluruh puskesmas dan juga siaran keliling bersama dengan BPBD. Sesuai dengan pendapat Fajar (2009), menjelaskan tujuan utama KIE yaitu membangun atau menciptakan pemahamam dan pengertian bersama. Saling memahami atau mengerti bukan berarti harus menyetujui tetapi mungkin dengan komunikasi terjadi suatu perubahan sikap, pendapat, perilaku ataupun perubahan secara sosial. Sesuai dengan teori Azwar (2013) Pengalaman pribadi menjadi dasar pembentukan sikap, pengalaman pribadi haruslah meninggalkan kesan yang kuat. Sikap akan lebih mudah terbentuk apabila pengalaman pribadi tersebut terjadi dalam situasi yang melibatkan faktor emosional. 
Faktor emosional yang peneliti maksudkan berupa minum alkohol dapat meredakan emosi, menghilangkan stres, meningkatkan rasa percaya diri, membantu melupakan masalah. Sesuai dengan teori Azwar (2013), kadangkadang suatu bentuk sikap merupakan pernyataan yang didasari oleh emosi yang berfungsi sebagai semacam penyaluran frustasi atau pengalihan bentuk mekanisme pertahanan ego. Sikap demikian bersifat sementara dan segera berlalu begitu frustasi telah hilang, akan tetapi dapat pula merupakan sikap yang lebih persisten dan bertahan lama. Menurut Kelman (1958) dalam Azwar (2013) menyebutkan bahwa ada tiga proses sosial yang berperan dalam proses perubahan sikap, yaitu: kesediaan, indentifikasi dan internalisasi. Kesediaan adalah proses ketika individu bersedia menerima pengaruh dari orang lain atau dari kelompok lain dikarenakan ia berharap untuk memperoleh reaksi atau tanggapan positif dari pihak lain tersebut, seperti pujian, dukungan, simpati dan semacamnya. Identifikasi adalah apabila individu meniru perilaku atau sikap seseorang atau kelompok lain dikarenakan sikap tersebut sesuai dengan apa yang dianggapnya sebagai hubungan yang menyenangkan antara dia dengan pihak lain, untuk menopang pengertiannya sendiri mengenai hubungan tersebut proses perubahan sikap seseorang dapat dinilai dengan beberapa karakter atau dimensi. Penilaian sikap responden dalam penelitian ini hanya menilai karakter berupa arah saja, padahal ada 5 dimensi atau karakter cara menilai sikap yang dikemukakan oleh Azwar (2013), yaitu arah, intensitas, keluasan, konsitensi dan spontanitas. Arah adalah sikap terpilah pada dua arah kesetujuan (setuju/tidak setuju), mendukung atau tidak mendukung, memihak atau tidak memihak terhadap sesuatu atau seseorang. Orang yang setuju mendukung atau memihak terhadap suatu objek sikap, berarti memiliki sikap yang arahnya positif dan begitu sebaliknya. Intesitas adalah kedalaman atau kekuatan sikap terhadap sesuatu, belum tentu sama walaupun arahnya mungkin tidak berbeda. Keluasan adalah kesetujuan atau ketidaksetujuan terhadap suatu objek sikap, dapat hanya mengenai aspek yang sedikit dan sangat spesifik akan tetapi dapat pula sebaliknya. Konsistensi adalah kesesuaian antara pernyataan sikap yang dikemukakan dengan responnya terhadap objek sikap yang dimaksud. Spontanitas adalah menyangkut sejauh mana kesiapan individu untuk menyatakan sikapnya secara spontan. Suatu versi metode penanyaan langsung adalah pengungkapan langsung (direct assessment) secara tertulis yang dapat dilakukan dengan menggunakan item tunggal maupun dengan menggunakan item ganda. Pengetahuan adalah determinan yang paling berpengaruh $(\mathrm{p}=$ $0,006 ; \mathrm{OR}=12,783, \mathrm{CI} 95 \%=2,045-79,893)$ di mana penyuluhan yang intensif mengenai malaria perlu dilakukan untuk lebih menambah pengetahuan dan informasi masyarakat (Sukiswo, 2014). Oleh karenanya edukasi yang baik dan kompleks harus diberikan kepada masyarakat. Dalam komunikasi persuasi juga disebutkan bahwa komunikasi diperlukan untuk mengubah perilaku kesehatan secara langsung terkait dengan penyebab penyakit.

Adapun peran, gap dan optimalisasinya pada pencegahan dan penanggulangan Covid19 di Kota Pekalongan akan dijabarkan pada matrik tabel berikut ini :

Tabel 1 Peran, gap dan optimalisasinya pada pencegahan dan penanggulangan Covid-19 di Kota Pekalongan

\begin{tabular}{|c|c|c|c|}
\hline Pentahelix & Peran yang telah dilaksanakan & Gap yang terjadi & $\begin{array}{c}\text { Upaya optimalisasi yang } \\
\text { dapat dilakukan }\end{array}$ \\
\hline $\begin{array}{l}\text { Pemerintah dan } \\
\text { aparat }\end{array}$ & $\begin{array}{l}\text { Mengeluarkan produk kebijakan dan } \\
\text { penegakan peraturan wasdal gakkum } \\
\text { terkait pencegahan dan penanggu- } \\
\text { langan Covid-19 di Kota Pekalongan. } \\
\text { Pengalihalokasian beberapa anggaran } \\
\text { strategis guna akselerasi pencegahan } \\
\text { dan penanggulangan Covid-19 } \\
\text { melalui Refocusing. }\end{array}$ & $\begin{array}{l}\text { Produk kebijakan mengenai } \\
\text { pencegahan dan penanggu- } \\
\text { langan Covid-19 terdapat } \\
\text { kendala pada tataran imple- } \\
\text { mentasinya (ketidakpatu- } \\
\text { han masyarakat terhadap } \\
\text { 4M, pola penyeleng-garaan } \\
\text { kegiatan hajatan, pemberi- } \\
\text { an bantuan massal, seperti } \\
\text { IUMK, kegiatan keagama- }\end{array}$ & $\begin{array}{l}\text { Edukasi dan KIE masif } \\
\text { serta sosialisasi berkelan- } \\
\text { jutan secara terus menerus } \\
\text { mengenai pencegahan dan } \\
\text { pe-nanggulangan covid } 19 \\
\text { secara lintas program dan } \\
\text { lintas sektor. } \\
\text { Diperlukan adanya } \\
\text { evaluasi formatif dan }\end{array}$ \\
\hline
\end{tabular}




\begin{tabular}{|c|c|c|c|}
\hline Pentahelix & Peran yang telah dilaksanakan & Gap yang terjadi & $\begin{array}{c}\text { Upaya optimalisasi yang } \\
\text { dapat dilakukan }\end{array}$ \\
\hline & & an, ziarah dan seterusnya). & $\begin{array}{l}\text { sumatif terhadap program } \\
\text { Refocusing agar program } \\
\text { dapat berjalan dengan } \\
\text { efektiv dan efisien. }\end{array}$ \\
\hline Akademisi & $\begin{array}{l}\text { Telah melaksanakan elaborasi dengan } \\
\text { Pemkot Pekalongan melalui Dinkes } \\
\text { sebagai upaya pencegahan dan } \\
\text { penanggulangan Covid-19 melalui } \\
\text { kerja sama penyediaan dan rekru- } \\
\text { itment relawan Covid-19 yang terbuk- } \\
\text { ti cukup efektif di lapangan yang te- } \\
\text { lah dilaksanakan oleh Universitas Pe- } \\
\text { kalongan, selain itu juga komitment } \\
\text { telah tergalang antara Universitas } \\
\text { Pekalongan dengan Pemkot Kota } \\
\text { Pekalongan dalam bentuk Kampus } \\
\text { Siaga Candi. }\end{array}$ & $\begin{array}{l}\text { Belum seluruh kampus di } \\
\text { Kota Pekalongan berela- } \\
\text { borasi dengan Pemkot } \\
\text { Pekalongan. }\end{array}$ & $\begin{array}{l}\text { Diperlukan kerja sama dan } \\
\text { elaborasi dalam bentuk } \\
\text { bentuk lain guna memper- } \\
\text { kuat peran knowlegde } \\
\text { power dalam upaya } \\
\text { pencegahan dan penang- } \\
\text { gulangan Covid-19. }\end{array}$ \\
\hline Masyarakat & $\begin{array}{l}\text { Masyarakat Kota Pekalongan sebe- } \\
\text { narnya telah mengambil peranan aktif } \\
\text { dalam kegiatan pencegahan dan } \\
\text { penanggulangan Covid-19, hanya saja } \\
\text { belum diikuti dengan tingkat kepatu- } \\
\text { han terhadap penengaakan protokol } \\
\text { kesehatan. }\end{array}$ & $\begin{array}{l}\text { Tingkat kepatuhan terhadap } \\
\text { penegakan protokol } \\
\text { kesehatan masih memer- } \\
\text { lukan penguatan dari unsur } \\
\text { tokoh agama dan tokoh } \\
\text { masyarakat serta peng- } \\
\text { awalan dari aparat }\end{array}$ & $\begin{array}{l}\text { Sosialisasi, edukasi dan } \\
\text { persuasi penegakan proto- } \\
\text { kol kesehatan harus terus } \\
\text { diupayakan, terlebih pada } \\
\text { fasilitas-fasilitas umum } \\
\text { yang memungkinkan ber- } \\
\text { kumpulnya banyak orang } \\
\text { (pasar tradi-sional, cofee } \\
\text { shop, ziarah Sapuro, dll). }\end{array}$ \\
\hline Media & $\begin{array}{l}\text { Media lokal baik cetak maupun elek- } \\
\text { tronik, seperti TV Batik, Radar Peka- } \\
\text { longan telah melakukan KIE cukup } \\
\text { baik terkait pencegahan dan penang- } \\
\text { gulangan Covid-19, dan TV Batik } \\
\text { juga telah mengupayakan materi } \\
\text { edukasi selama daring masa pandemi. }\end{array}$ & $\begin{array}{l}\text { Media belum serta merta } \\
\text { mengambil peranan dalam } \\
\text { upaya modifikasi perilaku } \\
\text { masyarakat dalam kepa- } \\
\text { tuhan penegakan protokol } \\
\text { kesehatan }\end{array}$ & $\begin{array}{l}\text { Elaborasi antara media } \\
\text { sebagai information power } \\
\text { dengan akade-misi sebagai } \\
\text { know-ledge power perlu } \\
\text { diupayakan terus guna } \\
\text { mengisi konten konten } \\
\text { untuk dapat meng-giring } \\
\text { kepatuhan masyarakat } \\
\text { dalam penegakan protokol } \\
\text { kesehatan. }\end{array}$ \\
\hline Swasta & $\begin{array}{l}\text { Swasta dan manufacturing serta } \\
\text { pelaku usaha, ritel (seperti Hyper- } \\
\text { mart, Transmart, bidang perhotelan, } \\
\text { dan lainnya) telah mengupayakan } \\
\text { penegakan protokol kesehatan dalam } \\
\text { lingkup usaha mereka }\end{array}$ & $\begin{array}{l}\text { Peran swasta dalam } \\
\text { pencegahan dan penang- } \\
\text { gulangan Covid-19 di Kota } \\
\text { Pekalongan belum sampai } \\
\text { tahap kerjas ama maupun } \\
\text { CSR sehingga harapannya } \\
\text { dapat mengadopsi program } \\
\text { Refocusing, dan membantu } \\
\text { Pemkot dalam percepatan } \\
\text { penanggulangan Covid-19. }\end{array}$ & $\begin{array}{l}\text { Perlu kerja sama dan } \\
\text { kemitraan yang lebih } \\
\text { optimal dengan Pemkot } \\
\text { Pekalongan dalam akse- } \\
\text { lerasi penanggulangan } \\
\text { Covid-19, seperti pengem- } \\
\text { bangan program CSR atau } \\
\text { yang lainnya. }\end{array}$ \\
\hline
\end{tabular}

Pandemi Covid-19 yang telah ditetapkan sebagai bencana sosial, melahirkan kerja sama pentahelix (pemerintah, OPD leading sector dan lintas sektor, perguruan tinggi, BPBD) berupa upaya mitigasi bencana pandemi Covid19.

\section{KESIMPULAN DAN SARAN}

Analisis situasi umum pandemi Covid-19 di Kota Pekalongan masih dalam fase puncak pandemi sehingga kewaspadaan umum dan upaya awareness serta kepatuhan penegakkan protokol kesehatan masih harus terus dilaksanakan dan ditegakkan. Berdasarkan temuan penelitian peran dan optimalisasi pentahelix, seluruh unsur pentahelix 
(pemerintah, akademisi, masyarakat, media dan swasta) semuanya telah mengambil peranan walaupun terdapat beberapa hambatan implementasi di lapangan terutama pada profil dan tingkat kepatuhan masyarakat, pada khususnya di fasilitas umum seperti pasar tradisional, ziarah Sapuro, aktivitas keagamaan dan lainnya.

Diperlukan menghadirkan sosok tokoh agama dan tokoh masyarakat berpengaruh, mengingat kultur dan penciri sosial demografi masyarakat Kota Pekalongan yang religius dalam upaya mengubah dan memodifikasi perilaku masyarakat Kota Pekalongan yang di dalam penelitian ini terbukti tingkat kepatuhan dalam penegakan protokol kesehatan masih kurang.

Diperlukan penguatan koordinasi dan elaborasi untuk satunya data, alur-alur strategi akselerasi pencegahan dan penanggulangan Covid-19 yang disertai dengan evaluasi baik formatif maupun sumatif untuk seluruh peta program upaya akselerasi pencegahan dan penanggulangan Covid-19 di Kota Pekalongan yang telah berjalan sejak Februari 2020, sehingga diharapkan terjadi sinkronisasi program dan perbaikan upaya yang lebih efektif dan efisien.

\section{DAFTAR PUSTAKA}

Achmadi UF. Manajemen penyakit berbasis wilayah. Jakarta: Kompas; 2005. KESMAS, Jurnal Kesehatan Masyarakat Nasional Vol. 3, No. 4, Februari 2009 Achmadi, Manajemen Penyakit Berbasis Wilayah

Achmadi UF. Manajemen penyakit berbasis wilayah. Jakarta: UI Press; 2008. 4. Achmadi UF. Horison baru kesehatan masyarakat di Indonesia. Jakarta: Rineka Cipta; 2008.

Achmadi UF. Paradigma kesehatan lingkungan dan kesehatan kerja. Mimeograph: FKM UI;1987.

Achmadi UF. Transformasi kesehatan lingkungan dan kesehatan kerja di Indonesia. Pidato Pengukuhan Guru Besar
UI. Depok: Dokumen Perpustakaan FKMUI; 1991.

Achmadi. Manajemen Penyakit Berbasis Wilayah. Jurnal Kesehatan Masyarakat Nasional Vol. 3 No. 4 Februari 2009. DOI:http://dx.doi.org/10.21109/kesmas.v3i 4.217

Anggraeni, P., Heridadi, H., \& Widana, I. K. (2018). Faktor risiko (breeding places, resting places, perilaku kesehatan lingkungan, dan kebiasaan hidup) pada kejadian luar biasa demam berdarah dengue di kecamatan cikupa kabupaten tangerang. Jurnal Manajemen Bencana $(J M B), 4(1)$.

Aspuah, Siti. 2013. Kumpulan Kuesioner dan Instrumen Penelitian Kesehatan. Yogyakarta : Nuha Medika.

Azwar, Saifuddin. 2013. Sikap Manusia, Teori dan pengukurannya, Edisi 2. Yogyakarta: Pustaka Pelajar.

D.Noor. (2014). Geomorfologi, Edisi Pertama, Penerbit Deepublish (CV Budi Utama): Yogyakarta

Fajar, 2009. Ilmu Komunikasi Teori dan Praktik. Yogyakarta: Graha Ilmu.

Nisa Farichatun. (2014).Manajemen Penanggulangan Bencana Banjir, Putting Beliung, dan Tanah Longsor di Kabupaten. JKMP (Jurnal Kebijakan dan Manajemen Publik) 2(2):103.DOI: 10.21070/jkmp.v2i2.432

Mona, Nailul. (2020). Konsep Isolasi Dalam Jaringan Sosial Untuk Meminimalisasi Efek Contagious (Kasus Penyebaran Virus Corona Di Indonesia). Jurnal Sosial Humaniora Terapan Universitas Indonesia. Vol. 2 No. 2.

Solehudin, Usep. 2005. Business Continuity and Disaster Recovery Plan. Depok: Universitas Indonesia

Susanto, A.B. (2006). Disaster Management di Negeri Rawan Bencana. Jakarta: Aksara Grafika Pratama.

UU Nomor 24 Tahun 2007 Tentang Penanggulangan Bencana(Pasal 1 ayat 6 PP No 21 Tahun $2008 \quad$ Tentang Penyelenggaraan Penanggulangan Bencana) 